\section{Drinking produced by blood volume manipulation in weanling and adult rats}

\author{
FREDERICK J. KOZUB \\ University of Richmond, Richmond, Va. 23173
}

Twenty-five- and 90-day-old rats were subjected to extracellular volemic stress induced by subcutaneous injections of formalin or polyethylene glycol. Young rats responded to volemic stress by increasing their intake of water, as did adults; however, young rats showed a hyperreactivity (exaggerated intake) to volemic stress. This finding may reflect a behavioral compensation for the immaturity of the young animals' excretion controlling mechanisms.

When the tonicity of extracellular fluid (ECF) is decreased, thirst seems to appear only when intravascular volume is also decreased. Formalin introduced subcutaneously produces this effect physiologically and produces drinking in adult rats (Stricker, 1966; Stricker \& Wolf, 1966). Acute decreases in the volume without changes in ECF tonicity can be produced by subcutaneous administration of polyethylene glycol (PG) which is also a potent stimulus for drinking (Corbit, 1968; Stricker, 1966; Stricker \& Wolf, 1966, 1969).

The mediational systems for regulating the volume of ECF have been reviewed elsewhere (Pitts, 1968; Woodbury, 1966). Briefly, the system involves some receptor sensitive to blood volume (distention of the left atrium or the thyro-carotid arterial junction) and/or to changes in the flow or pressure of the blood entering the kidney. Also involved are appropriate neural and hormonal components of the hypothalamicpituitary-adrenal-kidney axis.

Mechanisms implicated in such a response by the adult are known to be immature in the young rat. Mikulás et al (1961) have shown that mineral-corticoids produced by the adrenal glands, one of which is aldosterone, are secreted in very small amounts by young animals. If the young rat has an aldosterone "insufficiency," one might expect it to increase its intake of water when subjected to volemic stress as less water will be reabsorbed into the vascular system by the kidney than is necessary to restore the volume deficit. Immature functioning of the kidney as demonstrated by Falk (1955) would also place a greater burden on water intake as a mode of restoring the ECF volume deficit. There is, however, the possibility that mechanisms controlling renal function are also involved in mobilizing drinking. Fitzsimons (1969) has shown that renal extracts (probably containing renin) produce drinking and that angiotensin injected intracranially (Epstein et al, 1969) or intravenously (Fitzsimons \& Simons, 1969) also produces drinking. If the mechanisms controlling renal function (which also mobilize drinking) are immature in the young rat, then lessened intake would obtain.

The present study was designed to observe drinking in young animals when the dipsogenic stress was ECF volume reduction.

\section{METHOD}

Six independent groups of four Ss each were tested. Animals were maintained on ad lib food and water. Ss were injected subcutaneously with either polyethylene glycol (mol wt 40,000 ), formalin, or $0.9 \% \mathrm{NaCl}$ (wt/volume) at 25 or 90 days. The

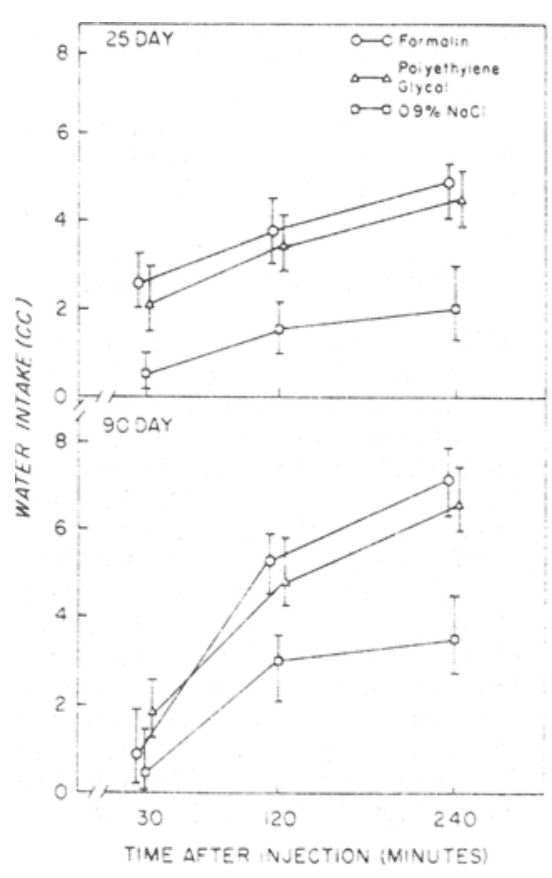

Fig. 1. Means and ranges for water intake in 25- and 90-day-old rats after subcutaneous injection with ECF volume manipulants. Connected points represent means; vertical lines represent ranges. amounts of fluid injected into both the 25- and 90-day-old rats were: polyethylene glycol, $2.0 \%$ body weight (bw); formalin, $1.0 \% \mathrm{bw}$; and $0.9 \%$ $\mathrm{NaCl}, 1.7 \%$ bw (formalin and polyethylene glycol were injected in a $0.9 \% \mathrm{NaCl}$ vehicle).

RESULTS AND DISCUSSION

Figure 1 depicts the means and ranges for water intake in 25- and 90-day-old rats at various times after injection. It can be seen that the curves are quite similar in shape and that young animals, as well as adults, increase their intake of water in response to ECF volume manipulants as compared with the effects of the isotonic-saline vehicle $(\mathrm{p}<.05$, Fisher test, tested at $4 \mathrm{~h}$ after injection).

Table 1 shows water intake per unit body weight in 25- and 90-day-old rats. Water intake is higher in young animals ( $p<.01$ in each case, Fisher test) for formalin, $\mathrm{PG}$, and $0.9 \% \mathrm{NaCl}$.

Table 1

Water Intake (Percent Body Weight) in 25 . and 90-Day-Old Rats $4 \mathrm{H}$ After Subcu. taneous Injection of Various ECF Volume Manipulants

\begin{tabular}{lcc}
\hline \multirow{2}{*}{$\begin{array}{c}\text { Injected } \\
\text { Substances }\end{array}$} & \multicolumn{2}{c}{ Age (Days) } \\
\cline { 2 - 3 } & 25 & 90 \\
\hline Formalin & 0.44 & 0.11 \\
Poly ethlene Gly col & 0.42 & 0.10 \\
$0.9 \% \mathrm{NaCl}$ & 0.16 & 0.06 \\
\hline
\end{tabular}

These data support the hypothesis that the young rat, even though its physiological mechanisms for regulating body water are incomplete by adult standards, is responsive to volume manipulations of ECF which lead to drinking. In addition, the young animal also shows a hyperresponsiveness to volume manipulants.

It is conceivable that this hyperresponsiveness is a release phenomenon reflecting functional immaturity of inhibitory systems (Stricker, 1969). On the other hand, noting that the mechanisms which control urine output are slow to mature in the rat, a more likely explanation of our findings is that the immaturity of excretory mechanisms places a greater burden upon intake as a way of coping with hydrational stress.

This latter hypothesis implies that intake mechanisms reach full competence before the excretory mechanisms do, and to that extent they are independent. Indeed, Cápek \& Jelinek (1955) have shown that spontaneous urination does not occur until the rat is approxiamtely 14 days of age, well after the time it has started suckling.

It is quite possible that, in behaving differently from the adult, the young 
animal is behaving in a manner appropriate to the demands imposed by its characteristic environment and the maturational levels of its other regulatory mechanisms.

CÀPEK, K.: \& JELINEK, J. The development and control of water metabolism: I. The excretion of urine in young rats. Physiologia Bohemsolvenia, $1956,5,91-98$.

CORBIT, J. D. Cellular dehydration and hypovolemia are additive in producing thirst. Nature, $1968,218,886-887$.

EPSTEIN, A. N.. FITZSIMONS, J. T., \& SIMONS, B. J. Drinking caused by the intracranial injection of angiotensin into the rat. Journal of Physiology, 1969, 200. 98-100P.
FALK, G. Maturation of renal function in infant rats. American Journal of Physiology, 1955, 181, 157-170.

FITZSIMONS, J. $T$. The role of a renal thirst factor in drinking induced by extracellular stimuli. Journal of Physiology, 1969, 201, 349-368.

FITZSIMONS, J. T. \& SIMONS, B. J. The effect on drinking in the rat of intravenous infusion of angiotensin given alone or in combination with other stimuli of thirst. Journal of Physiology, $1969,203,45-75$.

MIKULAS, I., DLOUHA, H., KRËCEK, J., KRECEKOVÁ, J., KU KE, J., \& VACEK, $Z$. The intake of water and electrolytes in relation to the development of homeostatis. The development of homeostasis. Prague: Ceskoslovenská Akademie Vèd., 1961.

PITTS, R. F Physiology of the kidney and body fluids. New York: Year Book Medical Publishers, 1968.
STRICKER, E. M. Extracellular fluid volume and thirst. American Journal of Physiology, 1966, 211, 232-238.

STRICKER E. M. Osmoregulation and volume regulation in rats: Inhibition of hypovolemic thirst by water. American Journal of Physiology, 1969, 217, 98-105.

STRICKER, E. M., \& WOLF, G. Blood volume and tonicity in relation to sodium appetite. Journal of Comparative \& Physiological Psychology, 1966, 62, 275-279.

STRICKER, E. M., \& WOLF, G. Behavioral control of intravascular fluid volume: Thirst and sodium appetite. Annals of the New York Academy of Science, 1969, Vol. 157, Art. 2, 553-568.

WOODBURY, D. M. Physiology of body fluids. In $T$. Ruch and $H$. Patton (Eds.), Physiology and biophysics. (19th ed.) Philadelphia: Saunders, 1966. PP. 871-889.

\section{CURRENT LITERATURE ON ANIMAL MOTIVATION}

ABEL, E. L. (University of Totonto, Toronto 181, Ontario, Canada). Habituation as a factor in early handling. Journal of Comparative and Physiological Psychology, 1971, 74, 219-221.

BLASS, E. M. (Johns Hopkins University, Baltimore, Md. 21218). Effects of frontal-pole-area ablation on temperature regulation in the rat. Journal of Comparative and Physiological Psychology, 1971, 74, 233-239.

BORER, K. T. (Physiological Research Laboratory, Scripps Institution of Oceanography, La Jolla, Calif. 92037). Control of food intake in Octopus briareus Robson. Journal of Comparative and Physiological Psychology, 1971, 75, 171-185.

CARLISLE, H. J. (University of California, Santa Barbara, Calif. 93106). Fixed-ratio polydipsia: Thermal effects of drinking, pausing, and responding. Journal of Comparative and Physiological Psychology, 1971, 75, 10-22.

DEAUX, E. (Antioch College, Yellow Springs, Ohio 45387), \& KAKOLEWSKI, J. W. Character of osmotic changes resulting in the initiation of eating. Journal of Comparative and Physiological Psychology, 1971, 74, 248-253.
DUNCAN, N. C., GROSSEN, N. E., \& HUNT, E. B. (University of Washington, Seattle, Wash. 98105). Apparent memory differences in inbred mice produced by differential reaction to stress. Journal of Comparative and Physiological Psychology, 1971, 74, 383-389.

FERGUSON, N. B. L., \& KEESEY, R. E. (University of Wisconsin, Madison, Wis. 53706). Comparison of ventromedial hypothalamic lesion effects upon feeding and lateral hy pothalamic self-stimulation in the female rat. Journal of Comparative and Physiological Psychology, 1971, 74, 263-271.

FRUMKIN, K. (McGill University, Montreal 110, Quebec, Canada). Interaction of $\mathrm{LiCl}$ aversion and sodium-specific hunger in the adrenalectomized rat. Journal of Comparative and Physiological Psychology, 1971, 75, 32-40.

GLENDENNING, R. L., \& MEYER, D. R. (202 Kinnear Research Center, Ohio State University, Columbus, Ohio 43212). Motivationally related retroactive interference in discrimination learning by rats. Journal of Comparative and Physiological Psychology, 1971, 75, 153-156.
GROSSMAN, S. P. (University of Chicago, Chicago, Ill. 60637). Changes in food and water intake associated with an interruption of the anterior or posterior fiber connections of the hypothalamus. Journal of Comparative and Physiological Psychology, 1971, 75, 23-31.

LEACH, D. A. (College of Wooster, Wooster, Ohio 44691). Rats' extinction performance as a function of deprivation level during training and partial reinforcement. Journal of Comparative and Physiological Psychology, 1971, 75, 317-323.

MAIER, S. F. (University of Ilinois, Champaign, Ill. 61820), ZAHORIK, D. M., \& ALBIN, R. W. Relative novelty of solid and liquid diet during thiamine deficiency determines development of thiamine-specific hunger. Journal of Comparative and Physiological Psychology, 1971, 74, 254-262.

MARWINE, A. G., \& COLLIER, G. (Rutgers-The State University, New Brunswick, N.J. 08903). Instrumental and consummatory behavior as a function of rate of weight loss and weight maintenance schedule. Journal of Comparative and Physiological Psychology, 1971, 74, 441-447. 